\title{
Correction: Theoretical analysis of the evolution of immune memory
}

\author{
Frederik Graw ${ }^{*+}$, Carsten Magnus ${ }^{*+}$, Roland R Regoes
}

\begin{abstract}
After the publication of this work [1], we became aware of the fact that the originally published Figure S-Three in the Additional file 1 was based on incorrectly simulated data. This simulation was accidentally performed with wrong parameter values for the total memory pool size $n_{\mathrm{mp}}$. As a consequence, Figure S-Three did not show the analysis we described in the figure legend. We repeated the simulations with the correct parameter values. The revised Figure S-Three does not change our conclusions and further corroborates the claims we made in the main manuscript (p.6 Results - Replacement type): "There is no clear preference for the one or the other replacement type for specific fractions of memory pool replaced as the relative fitness differs very little from one. In general, the trend of the relative fitness estimated between different replacement types is independent of the pathogen environment. These findings are consistent for different memory pool sizes $n_{\mathrm{mp}}$."

We regret any inconvenience that the incorrect Figure in the original article might have caused.
\end{abstract}

\section{Additional material}

Reference

1. Graw F, Magnus C, Regoes RR: Theoretical analysis of the evolution of immune memory. BMC Evolutionary Biology 2010, 10:380.

doi:10.1186/1471-2148-11-54

Cite this article as: Graw et al:: Correction: Theoretical analysis of the evolution of immune memory. BMC Evolutionary Biology 2011 11:54.
Received: 21 February 2011 Accepted: 28 February 2011

Published: 28 February 2011

\footnotetext{
* Correspondence: frederik.graw@env.ethz.ch; carsten.magnus@env.ethz.ch † Contributed equally

Integrative Biology, ETH Zurich, Switzerland
}

Submit your next manuscript to BioMed Central and take full advantage of:

- Convenient online submission

- Thorough peer review

- No space constraints or color figure charges

- Immediate publication on acceptance

- Inclusion in PubMed, CAS, Scopus and Google Scholar

- Research which is freely available for redistribution

Submit your manuscript at www.biomedcentral.com/submit

\section{() Biomed Central}

C Biomed Central

(C) 2011 Graw et al; licensee BioMed Central Ltd. This is an Open Access article distributed under the terms of the Creative Commons Attribution License (http://creativecommons.org/licenses/by/2.0), which permits unrestricted use, distribution, and reproduction in any medium, provided the original work is properly cited. 